\title{
THE IN SERVICE TRAINING IN IMPROVING TEACHERS PERFORMANCE IN LEARNING PROCESS
}

\author{
Yetti Ellyana \\ Dinas Pendidikan dan Kebudayaan, Riau, Indonesia \\ yettiellyana@gmail.com
}

\begin{abstract}
The in-service training program is a training or coaching effort that gives an opportunity for someone who gets a certain job assignment, in that case, is a teacher, to get performance development. This research is a school action research (PTS). This research was conducted SDN 006 Kelawat District of Sei Lala in the academic year 2017/2018. Research data collection is done by obtaining an assessment of teacher performance in the learning process seen from indicators (a) Preparation of Actions, (b) Implementation of Actions, (c) Monitoring and Evaluation, (d) Reflection. Indicators of success achieved by researchers in this study are if the percentage of average success of all class teachers $\geq 85$. Based on the results of the study found that there was a significant increase from cycle I to cycle II. This can be seen from the overall average rating in cycle I 69.75 increasing to cycle II to 86.62. Then the learning planning indicators increased from 65.71 to 85.7. On the value of the implementation of learning the teacher's value from 70 increased to 88.57. The value in assessing student achievement increased from 74.29 to 82.14 . Likewise in the aspect of carrying out the follow-up of research results from 67.86 to 90. Based on these improvements it is known that the in-service training method can improve teacher performance in SDN 006 Kelawat District of Sei Lala.
\end{abstract}

Keywords: service training, teacher performance

\section{PENERAPAN IN SERVICE TRAINING DALAM MENINGKATKAN KINERJA GURU DALAM PROSES PEMBELAJARAN}

\begin{abstract}
ABSTRAK
Program in service training adalah suatu usaha pelatihan atau pembinaan yang memberi kesempatan kepada seseorang yang mendapat tugas jabatan tertentu dalam hal tersebut adalah guru, untuk mendapat pengembangan kinerja. Penelitian ini merupakan penelitian tindakan sekolah (PTS). Penelitian ini dilaksanakan SDN 006 Kelawat Kecamatan Sei Lala tahun pelajaran 2017/2018. Pengumpulan data penelitian dilakukan dengan memperoleh penilaian kinerja guru dalam proses pembelajaran dilihat dari indikator (a) Persiapan Tindakan, (b) Pelaksanaan Tindakan, (c) Pemantauan dan Evaluasi, (d) Refleksi. Indikator keberhasilan yang dicapai oleh peneliti dalam penelitian ini ialah apabila persentasi rata - rata keberhasilan dari keseluruhan guru kelas $\geq 85$. Berdasarkan hasil penelitian diperoleh bahwa terjadi peningkatan yang berarti dari siklus I ke siklu II. Hal ini dapat dilihat dari rata-rata keseluruhan penilaian pada siklus I 69.75 meningkat ke siklus II menjadi 86.62. Kemudian pada indikator perencanaan pembelajaran yang meningkat dari 65.71 menjadi 85.7. Pada nilai pelaksanaan pembelajaran nilai guru dari 70 meningkat menjadi 88.57 . Nilai dalam menilai prestasi siswa meningkat dari 74.29 menjadi 82.14. Begitu juga pada aspek melaksanakan tindak lanjut hasil penelitian dari 67.86 menjadi 90. Berdasarkan peningkatan tersebut maka diketahui bahwa metode in service training dapat meningkatkan kinerja guru di SDN 006 Kelawat Kecamatan Sei Lala.
\end{abstract}

Kata Kunci: Service training, kinerja guru

\begin{tabular}{|c|c|c|}
\hline Submitted & Accepted & Published \\
\hline 27 Juli 2020 & 04 September 2020 & 25 September 2020 \\
\hline
\end{tabular}

\begin{tabular}{|l|l|l|l|l|}
\hline Citation & $:$ & Ellyana, Y. (2020). The In Service Training In Improving Teachers Performance In Learning Process. Jurnal PAJAR \\
\hline
\end{tabular}
(Pendidikan dan Pengajaran), 4(5), 957-964. DOI : http://dx.doi.org/10.33578/pjr.v4i5.8071.

\section{PENDAHULUAN}

Guru adalah orang yang paling penting statusnya di dalam kegiatan belajar-mengajar karena guru memegang tugas yang amat penting, yaitu mengatur dan mengemudikan bahtera kehidupan kelas. Bagaimana suasana kelas berlangsung merupakan hasil dari kerja guru. Suasana kelas dapat hidup, siswa belajar tekun tetapi tidak merasa terkekang, atau sebaliknya, suasana kelas suram, siswa kurang bersemangat dan diliputi rasa takut, itu semua sebagai akibat 
dari hasil pemikiran dan upaya guru (Suharsimi, 2009). Dengan demikian guru memiliki peran penting dalam mengelola kondisi kelas guna mencapai tujuan yang ingin dicapai. Kegiatan pembelajaran, dan hasil belajar peserta didik tidak saja ditentukan oleh manajemen sekolah, kurikulum, sarana dan prasarana pembelajaran, tetapi sebagian besar ditentukan oleh guru. Baik dan jeleknya prestasi siswa tergantung dari kinerja guru (Yamin \& Maisah, 2010).

Banyak faktor yang mempengaruhi kinerja guru. Faktor-faktor yang mempengaruhi kinerja guru meliputi tingkat pendidikan guru, supervisi pengajaran, program penataran (pelatihan), iklim yang kondusif, sarana dan prasarana, kondisi fisik dan mental guru, motivasi yang dimiliki, gaya kepemimpinan kepala sekolah, jaminan kesejahteraan, kemampuan manajerial kepala sekolah dan lain-lain. Kinerja guru bukan hanya mampu mengajar akan tetapi harus mengusai teknologi serta mampu mengembangkan proses pembelajaran yang aktip sehingga anak mampu mengembangkan secara optimal (Ningsih, dkk, 2020). Berdasarkan observasi awal di SDN 006 Kelawat Kecamtan Sei Lala ditemukan kendalakendala dalam pembuatan Rencana Pelaksanaan Pembelajaran (RPP), tidak semua guru menyusun RPP sesuai format, kemudian dalam pelaksanaan pembelajaran, masih ada guru yang belum dapat mengkondusifkan keadaan kelas menjadi tenang ketika ada siswa yang melakukan keributan dikelas, metode yang digunakan pun masih konvensional dan penggunaan media pembelajaran sebagai penunjangnya dan alat peraga lainnnya juga masih jarang sehingga yang terjadi pembelajaran terasa membosankan bagi siswa.

Salah satu tugas manajer atau kepala sekolah dan pengawas terhadap guru salah satunya adalah melakukan penilaian atas kinerjanya. Penilaian ini mutlak dilaksanakan untuk mengetahui kinerja yang telah dicapai oleh guru, baik, sedang, atau kurang (Ahmad, 2017). Kegiatan pengawas memberikan pengawasan kepada guru-guru pada sekolah binaan untuk meningkatkan profesionalisme dan peningkatan kinerja guru melalui service traning sebagai salah satu kegiatan dalam memberikan pelatihan untuk meningkatkan pada kegiatan pembelajaran (Wahyuni, 2020).

Maka kinerja guru yaitu berkaitan dengan tugas perencanaan, pengelolalan pembelajaran dan penilaian hasil belajar siswa. Sebagai perencana, maka guru harus mampu mendesain pembelajaran yang sesuai dengan kondisi di lapangan, sebagai pengelola maka guru harus mampu menciptakan iklim pembelajaran yang kondusif sehingga siswa dapat belajar dengan baik, dan sebagai evaluator maka guru harus mampu melaksanakan penilaian proses dan hasil belajar siswa (Sanjaya, 2005; Kartika, 2017). Kemampuan profesional guru, komitmen, disiplin dan motivasi, kinerja guru juga merupakan hal yang tidak kalah pentingnya. Kinerja seorang guru dikatakan baik jika guru telah melakukan unsur-unsur yang terdiri dari kesetiaan dan komitmen yang tinggi pada tugas mengajar, menguasai dan mengembangkan bahan pelajaran, kedisiplinan dalam mengajar dan tugas lainnya, kreativitas dalam pelaksanaan pengajaran, kerjasama dengan semua warga sekolah, kepemimpinan yang menjadi panutan siswa, kepribadian yang baik, jujur, dan objektif dalam membimbing siswa, serta tanggung jawab terhadap tugasnya. Membahas masalah kualitas dari kinerja guru tidak terlepas dari pencapaian hasil belajar (Rahardja, 2004; Inayatullah, 2011; Yasnawati dkk, 2013; Madjid, 2016).

Mengembangkan materi pembelajaran, tidak semua guru mengembangkan materi secara maksimal. Hal tersebut dikarenakan, guru hanya mengembangkan materi secara standar saja, dengan alasan apabila terlalu luas dikhawatirkan siswa kurang menguasai apa yang menjadi inti dari materi yang disampaikan guru, selain itu juga di karenakan kurangnya sumber belajar sebagai literatur dan referensi dalam pembelajaran dan kurangnya kemampuan guru dalam mengembangkan materi (Fanggidae \& Radja, 2020). Hasil observasi tersebut guru mengatakan jarang mengikuti program pelatihan dikarenakan sibuk dengan kegiatan yang ada di sekolah. Pelatihan adalah suatu proses yang meliputi serangkaian tindak (upaya) yang dilaksanakan dengan sengaja dalam bentuk pemberian bantuan 
kepada tenaga kerja yang dilakukan oleh tenaga profesional kepelatihan dalam satuan waktu yang bertujuan untuk meningkatkan kemampuan kerja peserta dalam bidang pekerjaan tertentu guna meningkatkan efektivitas dan produktivitas dalam suatu organisasi (Hamalik, 2007).

Program In-Service Education/ In service training adalah suatu usaha pelatihan atau pembinaan yang memberi kesempatan kepada seseorang yang mendapat tugas jabatan tertentu dalam hal tersebut adalah guru, untuk mendapat pengembangan kinerja. In service training juga bisa dikatakan sebagai suatu program sekaligus metode pelatihan dan pendidikan dalam jabatan yang dilaksanakan dengan cara langsung bekerja di tempat untuk belajar dan meniru suatu pekerjaan dibawah bimbingan seorang pengawas. Istilah lain yang juga dipergunakan ialah Upgrading atau penataran dan inservice education yang pada dasarnya mempunyai maksud yang sama. In service training diberikan kepada guruguru yang dipandang perlu meningkatkan ketrampilan/pengetahuannya sesuai dengan perkembangan ilmu pengetahuan, khususnya dibidang pendidikan (Purwanto, 2016).

\section{METODE PENELITIAN}

Penelitian ini merupakan penelitian tindakan sekolah maka pelaksanakan ini dilaksanakan secara siklus. Pelaksanaannya selama dua siklus. Siklus-siklus itu merupakan rangkaian yang saling berkelanjutan, maksudnya siklus kedua merupakan kelanjutan dari siklus pertama. Setiap siklusnya selalu ada persiapan tindakan, pelaksanaan tindakan, pemantauan dan evaluasi, dan refleksi (Timotius, 2017; Rolialis, 2019). Penelitian ini SDN 006 Kelawat Kecamtan Sei Lala tahun pelajaran 2017/2018. Waktu penelitian adalah pada bulan November tahun 2017. Selama penelitian tersebut peneliti mengumpulkan data awal, menyusun program in servise training, pelaksanaan program, analisis, dan tindak lanjut.

Penelitian ini pengumpulan data awal diambil dari daftar keadaan guru untuk mengetahui pendidikan terakhir, pelatihan yang pernah diikuti guru, serta lamanya guru bertugas.
Data awal kerja guru dan efektivitas pembelajaran dilihat dari hasil supervisi kunjungan kelas masing-masing guru sebelum dilaksanakan penelitian. Mengadakan pertemuan guru-guru sebagai mitra penelitian membahas langkahlangkah pemecahan masalah pembelajaran dari aspek guru, dan Peneliti. Merumuskan langkahlangkah tindakan yang akan dilaksanakan pada siklus pertama.

Pelaksanakan tindakan ini dilakukan oleh peneliti sebagai pengawas sekolah. Peneliti selama kegiatan belajar mengajar berlangsung dengan tindakan sebagai berikut: 1) Mengadakan penelitian guru selama membuat program pembelajaran. 2) Melaksanakan pelatihan in service training terhadap kendala guru dalam mengajar. Pada prinsipnya pemantauan dilaksanakan selama penelitian berlangsung, dengan sasaran utama untuk melihat peningkatan kemampuan guru serta efektivitas pembelajaran yang dilaksanakan oleh guru serta tindakantindakan Peneliti dalam mensupervisi guru tersebut. Refleksi merupakan kegiatan yang meliputi analisis, sintesis, memaknai, menerangkan, dan akhirnya menyimpulkan semua informasi yang diperoleh pada saat persiapan dan tindakan. Hasil refleksi dimanfaatkan untuk perbaikan pada siklus berikutnya. Peneliti (pengawas sekolah) dan Guru pada tahap ini mendiskusikan pelaksanaan proses tindakan yang dilakukan berdasarkan hasil pengamatan selama guru menyusun rencana pembelajaran, melaksanakan pembelajaran, menilai prestasi belajar, melaksanakan tindak lanjut hasil penilaian prestasi belajar siswa dan Peneliti melakukan tindakan. Hal yang didiskusikan meliputi: (a) kesesuaian pembelajaran dengan perencanaan, (b) materi yang digunakan pembelajaran, (c) evaluasi pembelajaran, (d) kesesuaian tindakan guru dengan format supervisi, (e) tindak lanjut Peneliti dan guru.

Data yang telah dikumpulkan dianalisis dengan menggunakan analisis kualitatif dan kuantitatif. Analisis kualitatif digunakan untuk menjelaskan perubahan perilaku guru dalam pembelajaran dan perilaku Peneliti dalam melaksanakan in service training. Adapun analisis 
kuantitatif digunakan untuk mengetahui keberhasilan guru berdasarkan. Indikator keberhasilan yang dicapai oleh peneliti dalam penelitian ini ialah apabila persentasi rata - rata keberhasilan dari keseluruhan guru kelas meningkat. Sedangkan tolak ukur nilai keberhasilan dari seorang guru sebesar $\geq 85$. Aspek-aspek kinerja guru yang ditujukan sebagai indikator keberhasilan, diantaranya:

a. Kinerja guru dalam menyusun rencana pembelajaran

b. kinerja guru dalam melaksanakan pembelajaran

c. Kinerja guru dalam menilai prestasi belajar siswa d. Kinerja guru dalam melaksanakan tindak lanjut hasil penilaian prestasi belajar siswa.

\section{HASIL DAN PEMBAHASAN}

Perencanaan yang berkaitan dengan pembuatan instrumen penelitian. Instrumen tersebut dibuat berdasarkan pada indikator yang dibuat oleh Departemen Pendidikan Nasional. Hasil pemantauan dalam membuat pembuatan format penilaian, perencanaan pembelajaran, melaksanakan pembelajaran, menilai prestasi, dan melaksanakan tindak lanjut hasil penilaian. Berdasarkan instrumen tersebut, guru akhirnya membuat perencanaan pembelajaran yang alurnya sama dengan instrumen supervisi tersebut hasil penelitian akan terlihat pada tabel 1 di bawah.

Tabel 1. Hasil Pelaksanaan Siklus I

\begin{tabular}{|c|c|c|c|c|c|c|c|c|}
\hline \multirow{2}{*}{ NO } & \multirow{2}{*}{\multicolumn{2}{|c|}{ Guru }} & \multicolumn{5}{|c|}{ Aspek Penilaian } & \multirow{2}{*}{ Rata-rata } \\
\hline & & & 1 & 2 & 3 & 4 & Jumlah & \\
\hline 1 & Guru A & & 70 & 75 & 70 & 70 & 285 & 71.25 \\
\hline 2 & Guru B & & 60 & 65 & 70 & 65 & 260 & 65 \\
\hline 3 & Guru C & & 70 & 75 & 65 & 70 & 280 & 70 \\
\hline 4 & Guru D & & 70 & 75 & 65 & 70 & 280 & 70 \\
\hline 5 & Guru E & & 60 & 65 & 70 & 65 & 260 & 65 \\
\hline 6 & Guru F & & 70 & 75 & 80 & 70 & 295 & 73.75 \\
\hline 7 & Guru G & & 60 & 65 & 70 & 65 & 260 & 65 \\
\hline 8 & Guru H & & 70 & 75 & 80 & 70 & 295 & 73.75 \\
\hline 9 & Guru I & & 75 & 75 & 80 & 70 & 300 & 75 \\
\hline \multirow[t]{3}{*}{10} & Guru J & & 70 & 65 & 70 & 70 & 275 & 68.75 \\
\hline & Jumlah & & 675 & 710 & 720 & 685 & 2790 & 697.5 \\
\hline & Rata-rata & & 67.5 & 71 & 72 & 68.5 & 279 & 69.75 \\
\hline
\end{tabular}

\section{Keterangan aspek:}

1. Perencanaan Pembelajaran

2. Melaksanakan Pembelajaran

3. Menilai Prestasi

4. Melaksanakan Tindak lanjut Penilaian

Berdasarkan rata-rata keseluruhan aspek penilaian adalah 69.75 , nilai ini masih di bawah 85 sehingga belum mencapai angka ketuntasan penilaian. Jika dilihat dari setiap aspek, aspel perencanaan pembelajaran memiliki rata-rata 67.5 , aspek melaksanakan pembelajaran adalah 71 , aspek menilai prestasi adalah 72 dan aspek melaksanakan tindak anjut penilaian adlah 68.5. Berdasarkan indikator keberhasilan penelitian ini, dapat diketahui bahwa nilai tersebut dibawah standar keberhasilan 85, sehingga siklus II harus 
dilanjutkan. Lebih jelas tergambar terlihat pada gambar 1.

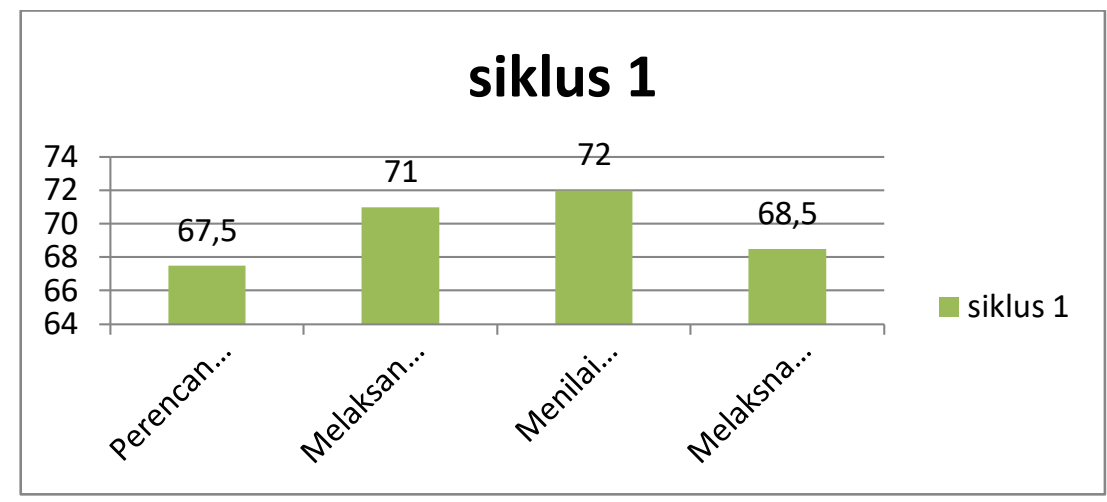

Gambar 1. Hasil Pelaksanaan Siklus I

Berdasarkan deskripsi data di atas maka peneliti melakukan tindak lanjut yang berkaitan dengan tindakan-tindakan yang perlu dilakukan pada siklus kedua, baik yang berkaitan dengan perencanaan, pelaksanaan, maupun penilaian.

1) Pada bagian penilaian peneliti melakukan refeksi in service training dan berdiskusi dengan guru lain untuk menentukan perencanaan pembelajaran dan tindak lanjut penilaian karena banyak bagian yang belum dipahami oleh guru-guru SDN 006 Kelawat Kecamatam Sei Lala.

2) Para guru SDN 006 Kelawat Kecamatam Sei Lala perlu pembinaan in service training tentang tindak lanjut penilaian, untuk membicarakan: (a) identifikasi tindak lanjut hasil penilaian, (b) menyusun program tindak lanjut, (c) Melaksanakan tindak lanjut, (d) mengevaluasi hasil tindak lanjut, (e) menganalisis hasil evaluasi program tindak lanjut hasil penilaian.

Pada siklus II merupakan lanjutan pertemuan dari siklus. Langkah-langkah yang dapat meningkatkan kinerja guru dalam in service training adalah: (1) Peneliti dan guru bersamasama membuat rencana pembelajaran dan program tindak lanjut hasil penilaian, (2) Peneliti memberi contoh membuat perencanaan penelitiam, pelaksanaan tindak lanjut, yang akhirnya dilanjutkan oleh guru dalam pelaksanaan yang sebenarnya. Hasil Pengamatan penelitian pada siklus II dapat dilihat pada tabel 2.

Tabel 2. Hasil Pelaksanaan Siklus II

\begin{tabular}{|c|c|c|c|c|c|c|c|}
\hline \multirow{2}{*}{ NO } & \multirow{2}{*}{ Guru } & \multicolumn{5}{|c|}{ Aspek Penilaian } & \multirow{2}{*}{ Rata-rata } \\
\hline & & 1 & 2 & 3 & 4 & Jumlah & \\
\hline 1 & Guru A & 90 & 95 & 90 & 80 & 355 & 88.75 \\
\hline 2 & Guru B & 90 & 70 & 95 & 85 & 340 & 85 \\
\hline 3 & Guru C & 80 & 95 & 95 & 90 & 360 & 90 \\
\hline 4 & Guru D & 85 & 90 & 80 & 90 & 345 & 86.25 \\
\hline 5 & Guru E & 85 & 80 & 95 & 90 & 350 & 87.5 \\
\hline 6 & Guru F & 95 & 80 & 80 & 95 & 350 & 87.5 \\
\hline 7 & Guru G & 90 & 85 & 90 & 80 & 345 & 86.25 \\
\hline 8 & Guru H & 80 & 90 & 80 & 80 & 330 & 82.5 \\
\hline 9 & Guru I & 95 & 90 & 80 & 70 & 335 & 83.75 \\
\hline 10 & Guru J & 95 & 80 & 90 & 90 & 355 & 88.75 \\
\hline
\end{tabular}


Jurnal PAJAR (Pendidikan dan Pengajaran)

Volume 4 Nomor 4 Juli 2020 | ISSN Cetak : 2580 - 8435| ISSN Online : 2614 - 1337

DOI : http://dx.doi.org/10.33578/pjr.v4i5.8010

\begin{tabular}{lcccccc}
\hline Jumlah & 885 & 855 & 875 & 850 & 3465 & 866.25 \\
Rata-rata & 88.5 & 85.5 & 87.5 & 85 & 346.5 & 86.62 \\
\hline
\end{tabular}

Berdasarkan rata-rata keseluruhan aspek penilaian adalah 86.62 , dimana nilai ini masih sudah melebihi 85 sehingga sudah mencapai angka ketuntasan penilaian. Jika dilihat dari setiap aspek, aspek perencanaan pembelajaran memiliki ratarata 88.5, aspek melaksanakan pembelajaran adalah 85.5 , aspek menilai prestasi adalah 87.5 dan aspek melaksanakan tindak anjut penilaian adlah 85. Berdasarkan indikator keberhasilan penelitian ini, dapat diketahui bahwa nilai tersebut memenuhi standar keberhasilan 85, sehingga siklus II selesai dan tidak dilanjutkan pada siklus selnjutnya. Perbandingan Nilai pada Siklus II dapat dilihat pada diagram berikut ini:

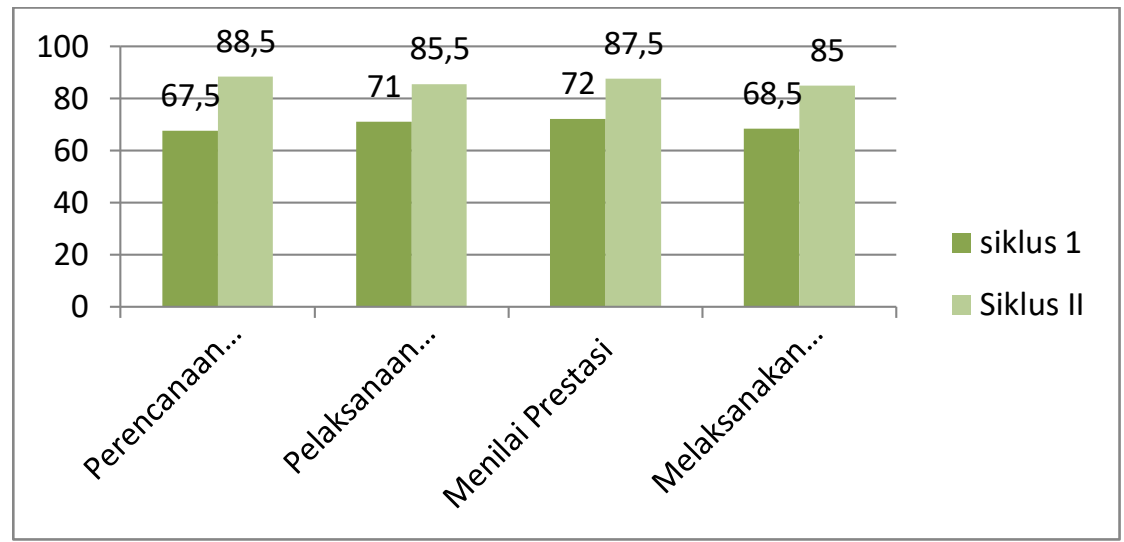

Gambar 2. Hasil Pelaksanaan Siklus I dan II

Berdasrkan diagram di atas dapat dilihat terdapat peningkatan dari siklus I ke siklu II. Hal ini dapat dilihat pada indikator perencanaan pembelajaran yang meningkat dari 67.5 menjadi 88.5. Pada nilai pelaksanaan pembelajaran nilai guru dari 71 meningkat menjadi 85.5. Nilai dalam pembelajaran nilai guru dari 71 meningkat menjadi 85.5. Nilai dalam menilai prestasi siswa meningkat dari 72 menjadi 87.5. Begitu juga pada aspek melaksanakan tindak lanjut hasil penelitian dari 68.5 menjadi 85. Penelitian ini dilakukan dengan meilhat penerapan metode in service training yang dilakukan dalam dua siklus penelitian. Perencanaan penelitian dilakukan dengan membuat format penilaian kinerga guru yaitu penialian pada a) Perencanaan Pembelajaran, b) pelaksanaan pembelajaran, c) penilaian prestasi dan pelaksanaan tindak lanjut hasil penilaian. Kemudian peneliti melakukan tidakan dengan metode in service training kepada guru guru berdasarkan langkah-langkah yang telah disiapkan. Setelah pembinaan ini selesai maka akan diadakan pengamatan. Dari hasil pengamatan akan dilihat tindakan apa yang akan dilaksanakan untuk tahap selanjutnya.

Kinerja guru merupakan faktor yang dominan dalam menentukan kualitas pembelajaran. Artinya kalau guru yang terlibat dalam kegiatan pembelajaran mempunyai kinerja yang bagus, akan mampu meningkatkan kualitas didalam pembelajaran sekolah, dengan salah satu cara memotivasi siswa untuk lebih giat belajar, untuk memotivasi belajar siswa dipengaruhi oleh kinerja guru dalam kelas. Berdasarkan Peraturan Manteri Pendidikan Nasional Republik Indonesia Nomot 16 tahun 2007 tentang Standar Kualifikasi Akademik dan Kompetensi Guru, kinerja guru yang harus dimiliki seorang guru yaitu: (1) Kompetensi Pedagogik, (2) Kepribadian, (3) Sosial, (4) Profesional (Madjid, 2016). Motivasi 
kinerja guru juga dipengaruhi oleh emosi dan teknologi sebagai keinginan untuk mengubah sikap terhadap perubahan secara individu (Kurniaman dkk, 2020). Sehingga mampu mengembangkan pembelajaran yang menarik siswa dengan mengembangkan media, metode pembelajaran yang bervariatif (Noviana, 2019).

\section{SIMPULAN DAN REKOMENDASI}

Berdasarkan temuan hasil penelitian ada empat hal yang dikemukakan dalam penelitian tindakan ini, yakni simpulan tentang: (1) Peningkatan kinerja guru dalam menyusun rencana pembelajaran, (2) Peningkatan kinerja guru dalam melaksanakan pembelajaran, (3) Peningkatan kinerja guru dalam menilai prestasi belajar, (4) Peningkatan kinerja guru dalam melaksanakan tindak lanjut hasil penilaian prestasi belajar siswa. Hasil penelitian pada indikator perencanaan pembelajaran yang meningkat dari 67.5 menjadi 88.5. Pada nilai pelaksanaan pembelajaran nilai guru dari 71 meningkat menjadi 85.5. Nilai dalam menilai prestasi siswa meningkat dari 72 menjadi 87.5. Begitu juga pada aspek melaksanakan tindak lanjut hasil penelitian dari 68.5 menjadi 85 . Dengan demikian dapat disimpulakan bahwa penerapan in service training dapat meningkatkan Kinerja Guru dalam proses pembelajaran di SDN 006 Kelawat Kecamtan Sei Lala.

\section{DAFTAR PUSTAKA}

Ahmad, L. O. I. (2017). Konsep Penilaian Kinerja Guru dan Faktor Yang Mempengaruhinya. Jurnal Idaarah, 1(1), 133-142.

Fanggidae, Y.M., \& Radja, M.D. (2020). Teacher's Social Support As A Predictor Motivation Of Student Achievements.Jurnal PAJAR (Pendidikan dan Pengajaran), 4(1), 11-19. DOI http://dx.doi.org/10.33578/pjr.v4i1.7911.

Hamalik, O. (2007). Proses Belajar Mengajar. Jakarta: PT Bumi Aksara.

Inayatulah. (2011). Kontribusi Faktor-Faktor Internal dan Eksternal terhadap Peningkatan Kinerja Profesional Guru. Jurnal Region, 3(1), 1-23.

Kartika. (2017). Kinerja Guru. [online] 20 Juli 2020. http://kartikainhil.blogspot.com/2017/12/m akalah-kinerja-guru.html.

Kurniaman, O., Noviana, E., Pratiwi, S. A., Maharani, D. S., Afendi, N. (2020). The Effect Of Smartphone On Student Emotions. International Journal Of Scientific \& Technology Research, 9 (01), $138-141$

Madjid. A. (2016). Pengembangan Kinerja Guru melalui Kompetensi, Komitmen dan Motivasi Kerja. DI Yogyakarta: Samudra Biru.

Ningsih, S., Kuntarto, E., \& Kurniawan, A.R. (2020). Teachers' Problems In Using Information And Communication Technology (ICT) And Its Implications In Elementary Schools. Jurnal PAJAR (Pendidikan dan Pengajaran), 4(3), 518524.

DOI:

http://dx.doi.org/10.33578/pjr.v4i2.7964.

Noviana, E., Kurniaman, O., Munjiatun., Sb Sismulyasih, N., \& Nirmala, S. D. (2019). Why Do Primary School Students Need Disaster Mitigation Knowledge? (Study Of The Use Of Koase Comics In Primary Schools). International Journal of Scientific \& Technology Research,8(11), 216-221.

Purwanto, N. (2016). Prinsip-prinsip dan Teknik Evaluasi Pengajaran. Bandung: PT Remaja Rosdakarya.

Rolialis. (2019). Upaya Meningkatkan Motivasi Kerja Melalui Supervisi Ademik Pada Guru SD di Kecamatan Lubuk Batu Jaya Kabupaten Indragiri Hulu. Primary: Jurnal Pendidikan Guru Sekolah Dasar, 8 (1), 20-27. DOI: http://dx.doi.org/10.33578/jpfkip.v8i1.705 3.

Rahardja, T. (2004). Hubungan antara Komunikasi antar Pribadi Guru dan Motivasi Kerja Guru dengan Kinerja Guru SMUK BPK Penabur Jakarta. Jurnal Pendidikan Penabur, 03 (Th.III), 1-21.

Suharsimi, A. (2009). Dasar-dasar Evaluasi Pendidikan. Jakarta: Bumi Aksara. 
Sanjaya,Wina. (2005). Pembelajaran dalam Implementasi Kurikulum Berbasis Kompetensi. Jakarta: Kencana.

Timotius, K. H. (2017). Pengantar Metodologi Penelitian Pendekatan Manajemen Pengetahuan untuk Perkembangan Pengetahuan. Yogyakarta: ANDI.

Wahyuni, S. (2020). Implementation Of The Academic Supervision Of The School Principal In Improving Teachers Performance On Teaching And Learning Process. Jurnal PAJAR (Pendidikan dan Pengajaran), 4(3), 635-643. DOI: http://dx.doi.org/10.33578/pjr.v4i2.7994.

Yasnawati, G.K.,Yudana, M., \& Natajaya, N. (2013). Kemampuan Manajerial, Motivasi Kepala Sekolah dan Profesionalisme Guru terhadap Kualitas Pembelajaran pada para Guru di SMA Se-Kecamatan Sukasada. EJournal Program Pascasarjana Universitas Pendidikan Ganesha. 4.

Yamin, M \& Maisah. (2010). Standarisasi Kinerja Guru. Jakarta: Persada Press. 